West Virginia Agricultural and Forestry Experiment Davis College of Agriculture, Natural Resources Station Bulletins

$1-1-1928$

\title{
Varietal Experiments with Tobacco
}

Theodore Clinton Mcllvaine

Ralph John Garber

Follow this and additional works at: https://researchrepository.wvu.edu/ wv_agricultural_and_forestry_experiment_station_bulletins

\section{Digital Commons Citation}

McIlvaine, Theodore Clinton and Garber, Ralph John, "Varietal Experiments with Tobacco" (1928). West Virginia Agricultural and Forestry Experiment Station Bulletins. 216.

https://researchrepository.wvu.edu/wv_agricultural_and_forestry_experiment_station_bulletins/216 @ WVU. It has been accepted for inclusion in West Virginia Agricultural and Forestry Experiment Station Bulletins by an authorized administrator of The Research Repository @WVU. For more information, please contact ian.harmon@mail.wvu.edu. 
West Virginia University Libraries 
EVANSDALE LIBRARY WEST VRGINIA UNWEERSTYY 


\section{Restricted}

Circulation Only

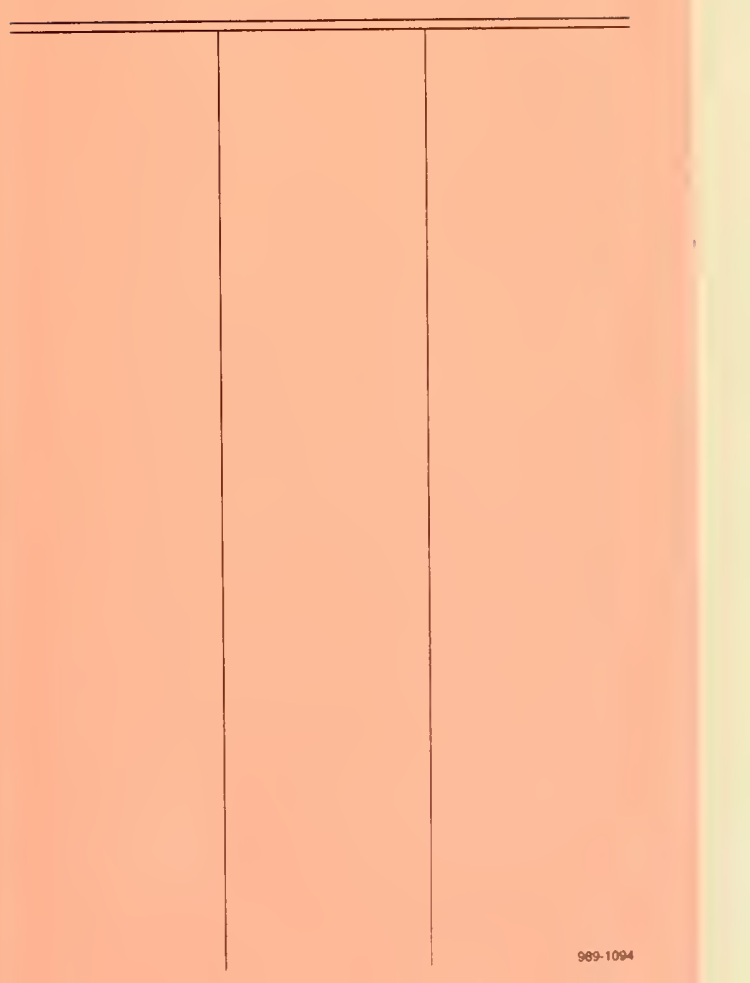





\section{Aurrunltural firpurintent Statiun}

College of Agriculture, West Virginia University

N. J. Giddings, Acting Director

Morgantown

\section{Tarietal Experiments With Tobacco}

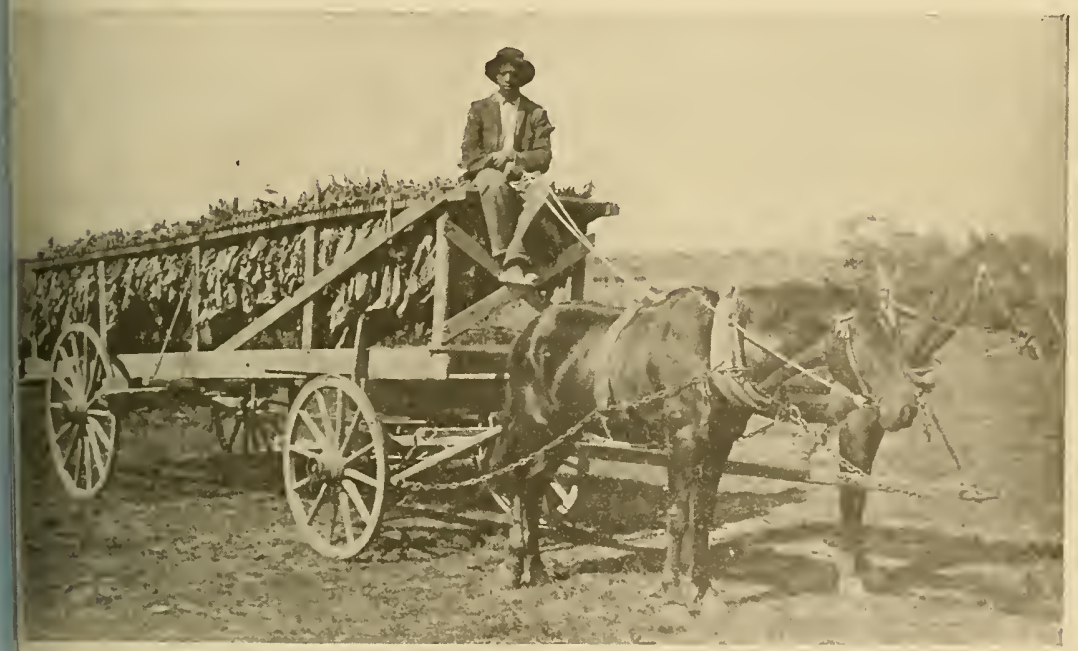

A ladder for hauling tobacco without injury

By

T. C. McILVAINE and R. J. GARBER

Publications of this Station will be mailed free to any citizen of West Virginia written application. Address Director of the Vest Virginia Agricultural ExperiStation, Morgantown, West Virginia. 


\section{AGRICULTURAL EXPERIMENT STATION STAFF}

FRANK BUTLER TROTTER, A. M., LL. D.

President of the Univer:y N. J. GIDDINGS, Ph. D. Acting Dean and Direc $r$ WALTER C. SCHNOPP, B. S. Agr. Agricultural Ed ir JOHN C. JOHNSTON. Chief $\mathrm{Cl}$

\section{AGRONOMY AND GENETICS}

R. J. Garber, Ph. D. Agronomist and Geneticist

E. P. Deatrick, Ph. D. Associate Agronomist (Soils)

T. E. Odland, Ph. D. Associate Agronomist

T. C. McIlvaine, Ph. D. $\div$ Assistant Agronomist (Soils)

D. R. Dodd, M. S.

M. M. Hoover, M. S

Assistant Agronomist

Junior Agronomist

H. K. Rowley, M. S. Agr.** Seed Analyst

ANIMAL HUSBANDRY

E. A. Livesay, M. S.

Animal Husbandman

Chas. V. Wilson, M. S.

Assistant Animal Husbandman

J. H. Longwell, M. A.

Assistant Animal Husbandman

J. H. Rietz, D. V. M.

Associate Veterinarian

R. H. Tuckwiller, B. S. Agr.*

Assistant Animal Husbandman

\section{CHEMISTRY}

R. B. Dustman, Ph. D.

Associate Chemist

Chas. E. Weakley, Jr., B. A.

Assistant Chemist

L. P. Hansen, Ph. D.

T. B. Leith, B. A.**

Assistant Chemist

Assistant Chemist

Leland Shriver

Assistant in Chemistry

\section{DAIRY HUSBANDRY}

E. L. Anthony, M. S. Agr.

Dairy Husbandman

H. O. Henderson, MI. S. Agr.

Associate Dairy Husbandman

G. Malcolm Trout, M. S.

Assistant Dairy Husbandman

\section{ENTOMOLOGY}

L. M. Peairs, Ph. D.

W. E. Rumsey, B. S.**

Entomologist

State Entomologist

L. E. Dills, M. S.**

Assistant in Entomology
FARM ECONOMICS

A. J. Dadisman, Ph. D.

Paul A. Eke, Ph. D.

Assistant Farm Econor

F. D. Cornell, Jr., M. S.

Junior Farm Mechanics

W. W. Armentrout, M. S.

Junior Farm Econorst

\section{HOME ECONOMICS}

Rachel H. Colwell, A. M.

Hazel C. Cameron, M. S.

Home Econor st

Research Specialist in Fdls

Nell Nesbitt, A. M.

Research Specialist in Home ?

\section{HORTICULTURE}

H. E. Knowlton, Ph. D.

Associale Horticulti

H. I. Crane, M. S. Agr.

K. C. Westover, M. S. Agr. Associate Horticultus

Ernest Angelo, M. S. Agr.

Junior Horticultıst

L. F. Sutton, B. S. Agr.

Assistant Horticultis

H. P. Sevy, M. S. Agr. Assistant in Horticul re

M. B. Hoffman, M. S. Assistant in Horticul ce

PLANT PATHOLOGY

N. J. Giddings, Ph. D.

Anthony Berg, M. S. Associate Plant Patholk st

L. H. Leonian, Ph. D. Associate Plant Pathols st

E. C. Sherwood, M. S. Assistant Plant Pathol, st

\section{POULTRY HUSBANDRY}

Horace Atwood, M. S. Agr. Poultry Husband an

E. T. Wightman, M. S. Agr. Junior Poultry Husband 20

RURAL SOCIOLOGY

T. L. Harris, Ph. D.

Rural Sociol's

\section{ZOOLOGY}

F. E. Chidester, Ph. D.

Zool

*In cooperation with the U. S. Department of Agriculture, Washington, D. C

IIn charge of the Lakin Sub-station, Lakin, W. Va.

* In cooperation with the State Department of Agriculture, Charlesion, W. V:

tin charge of the Reymann Memorial Farms, Wardensville, W. Va. 


\section{Varietal Experiments With Tobacco*}

The production of tobaceo in West Virginia is largely confined to ection embracing eight counties in the southwestern part of the te. These comntis are Gabell, Lineoln. P’uman, Mason, Wayne, kison. Boone, and Kanawha, of which the first three named produce roximately five million of the seren and one-half million pounds Aneed annually in the state.

The varieties of tobaeeo grown in this section belong, in the main, the Burley type which is used primarily for the manufacture of wing and smoking tobaceos. Inasmuch as no definite experimental dence as to the relative values of the different varieties grown this section was available, varietal experiments were begun in the ing of 1922 , at the Lakin substation in Mason County.

\section{IXPERIMENTAL METHODS AND SOURCES OF VARIETIES}

\section{Soil Treatment}

The plots on which the rarietal experiments were carried out were lled on first bottom land near the Ohio River. The soil was a highly ductive Huntington silt loam which had been in grass for several ris previous to its use for experimental purposes. The grass sod ; plowed in 1921 and planted to corn. In two of the four years in ch the varietal experiments were underway, tobacco followed corn in the other two years tobacco followed oats.

No fertilizer was applied to the tobacco or to any crop preceding The cropping plan followed and the lack of a fertilizer treatment not necessarily reeommended practiees. This procedure was folof in this case becanse of certain other experiments under way.) he spring of 1925 a heavy cover crop of rye was turned under for leeo.

\section{Varieties}

In Table 1 are listed the souree of seed and the seventeen varieties strains of tobaceo which were tested during the four-year period,

"The tobacco experiments at Lakin are calried on in cooperation with the Office of co Investigations, Bureau of Plant Industry, United States Department of ulture. The writers are indebted to Dr. W. W. Garner, Chief of that Office, for ,ble suggestions and for the photographs used in this bulletin.

ul)mitted for publication May, 1926. 
from 1922 to 1925, inclusive. Seed of most of the varieties was tained from the United States Department of Agriculture, Offic Tobacco Investigations. Five strains were obtained from the Kentu Agricultural Experiment Station, and one strain from the Hunting Tobacco Warehouse.

The variety designated as W. B. U. V. is a strain of drooping Burley, resistant to root-rot, which was developed at the Univer of Wisconsin. The five lots designated as S. B. No. 1, No. 9, No. 9a, $10 \mathrm{Ba}$, and No. $10 \mathrm{Fa}$, were, at the time of their introduction third fourth generation selections made in a cross between W. B. U. V. Judy's Pride, a strain of Standup Burley. Beinhart is' a pure selection of the drooping type of Kentucky White Burley. The st A. S. 7 is a selection from Vimont-Kelley and is resistant to root The history of the strain grown as Kentucky Selection is not know.

TABLE 1.-Tobaceo Varieties Tested and Sources of Seed with Reactio Root-rot and Character of Growth.

\begin{tabular}{|c|c|c|c|}
\hline $\begin{array}{l}\text { Names of Varieties } \\
\text { or Strains }\end{array}$ & $\begin{array}{l}\text { Sources } \\
\text { of Seed }\end{array}$ & $\begin{array}{c}\text { Reaction } \\
\text { to } \\
\text { Root-rot }\end{array}$ & $\begin{array}{c}\text { Character } \\
\text { of } \\
\text { Growth }\end{array}$ \\
\hline $\begin{array}{l}\text { Kelley } \\
\text { S. B. No. } 1 \\
\quad \text { No. } 9 \\
\quad \text { No. 9a } \\
\quad \text { No. 9Ba } \\
\quad \text { No. 9Fa } \\
\text { Kentueky Sclection } \\
\text { A. S. } 7 \\
\text { Judy's Pride } \\
\text { Pepper } \\
\text { Beinhart Sul. } 1917 \\
\text { W. B. U. V. } \\
\text { Halley } \\
\text { White Twist Bud } \\
\text { Red } \\
\text { Lockwood } \\
\text { Lockwood }\end{array}$ & $\begin{array}{l}\text { Ky. Exp. Station } \\
\text { U. S. Dept. of Agr. } \\
\text { U. S. Dept. of Agr. } \\
\text { U. S. Dept. of Agr. } \\
\text { U. S. Dept. of Agr. } \\
\text { U. S. Dept. of Agr. } \\
\text { Ky. Exp. Station } \\
\text { Ky. Exp. Station } \\
\text { U. S. Dept. of Agr. } \\
\text { Ky. Exp. Station } \\
\text { U. S. Dept. of Agr. } \\
\text { U. S. Dept. of Agr. } \\
\text { U. S. Dept. of Agr. } \\
\text { U. S. Dept. of Agr. } \\
\text { Ky. Exp. Station } \\
\text { U. S. Dept. of Agr. } \\
\text { Huntington Tobacco } \\
\text { Warehouse }\end{array}$ & $\begin{array}{l}\text { Non-resistant } \\
\text { Resistant } \\
\text { Resistant } \\
\text { Resistant } \\
\text { Resistant } \\
\text { Resistant } \\
\text { Resistant } \\
\text { Resistant }\end{array}$ & $\begin{array}{l}\text { Standup } \\
\text { Standup } \\
\text { Standup } \\
\text { Standup } \\
\text { Standup } \\
\text { Standup } \\
\text { Standup } \\
\text { Standup } \\
\text { Standup } \\
\text { Standup } \\
\text { Non-standup } \\
\text { Non-standup } \\
\text { Non-standup } \\
\text { Non-standup } \\
\text { Non-standup } \\
\text { Non-standup } \\
\text { Non-standup }\end{array}$ \\
\hline
\end{tabular}

Table 1 also shows the reaction of some of the strains of tobe to root-rot and the growth habit "standup" or "non-standup" all the strains in the test. The "standup" types have erect le, whereas the "non-standup" types have more or less drooping le.e

\section{Growing the Crop}

The plants for the varietal experiments were produced in the $1 t$ manner. Seed was sown about the middle of March in a prep 
erl-bed at the rate of a scant teaspoonful per 100 square feet of Irface. The seed was mixed with ashes to faeilitate a uniform distriution in sowing. After the seed was sown the surface of the entire ed bed was tramped firmly and then covered with a good grade of baceo muslin. It was neeessary, of course, to keep the seed bed well atered. The seedlings were transplanted to the plots between June 1 nd 10.

The plants were grown in rows $31 / 2$ feet apart and spaeed 18 inehes part in the rows. During the first three years of the experiment each lot was made up of three rows with fourteen plants per row. Only le twelve inner plants of the middle row were harvested for the yield ata. In 1925 eaeh plot was made up of four rows of the same length $\mathrm{s}$ in previous years and the yield reeord was obtained from twentyur plants of the two inner rows. End plants were disearded. In 923 each variety was grown in five plots, and in 1922, 1924, and 1925 1 four plots, systematically distributed over the entire experimental eld. During the latter two rears every third plot was used as a heek.

When the tobaceo on any partieular plot was fully matured, the alks' were split, eut, and then spudded. Six plants were plaeed on a ick. In this eondition, they were transported to a seaffold where rey remained until well wilted and then were hung in the tobaeco iring barn.

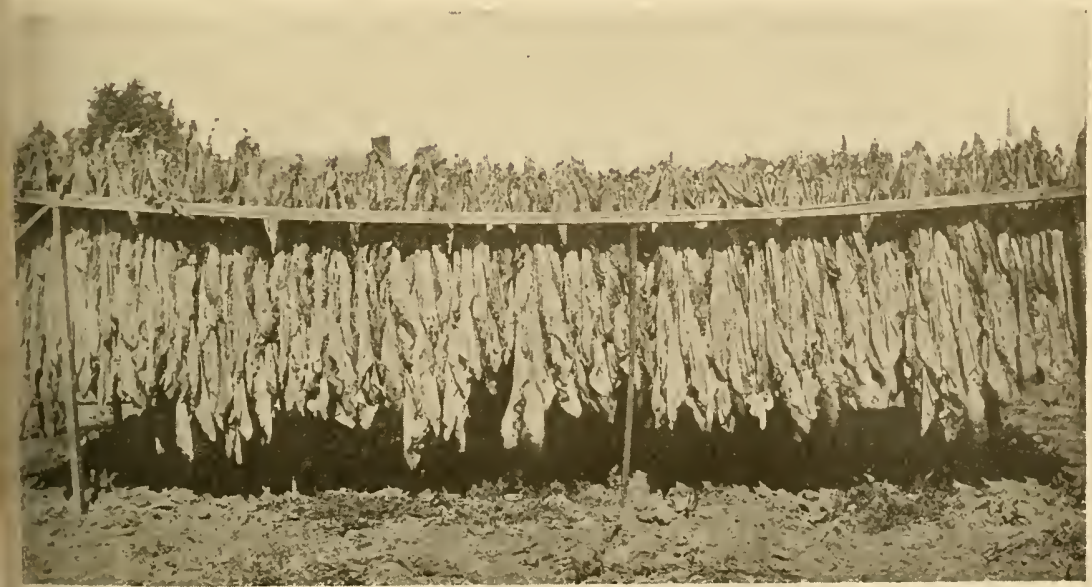

A scaffold in the field to facilitate the wilting of tobacco. 


\section{Grading}

Each year the tobacco was carefully graded. The sticks of tobacco were taken to a conditioning cellar until in proper "case" for handling. A sky-light in the grading room increased the intensity and uniformity of the light.

When the leaves were stripped from the stalks they were divided into a maximum of sixteen different grades, dependent on quality. The principal grades recognized by the Burley Tobaceo Growers Cooperative Association are: A, flyings; $\mathrm{B}$, trash; C, lugs; $\mathrm{D}$, bright leaf; E, red leaf; F, heavy tips; F. S., smok-

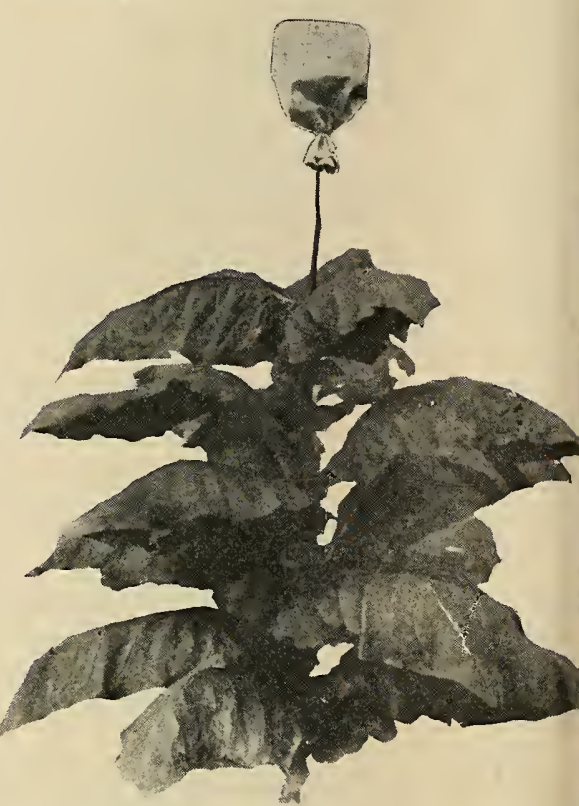

A tobacco plant with a 16-pound mar paper bag in place to prevent cross-po nation.

ing tip; C. W., cigarette wrapper; and T. W., twist wrapper. Each these grades, except the "smoking tip" and the two "wrappers," divided into seven classes, number one being the best and numl seven the poorest of a particular grade. In 1925, through the cou. esy of the Huntington Branch of the Burley Tobacco Growers' ( operative Association, it was possible to study the general relation tween the grading of the varieties at the substation and the offic grading of the same varieties, at Huntington. The results of ti study are recorded in Table 2.

The vertical columns in Table 2, numbered from one to sixtet contain the grades of tobaceo made at the Lakin substation, and $t$ twenty-two horizontal rows, labeled A7, A6, etc., contain the offic grades of tobacco made at Huntington. Beginning at the upper lt hand corner of Table 2 the official grades reading from the top dor and the grades made at the substation reading from left to right a arranged in the same order. Although the official grades and the st station grades do not exactly correspond, the relative position of $t$ gracles in one system as arranged in the table corresponds with th in the other system. In general, the substation grades are somewh more inclusive than the official grades. 


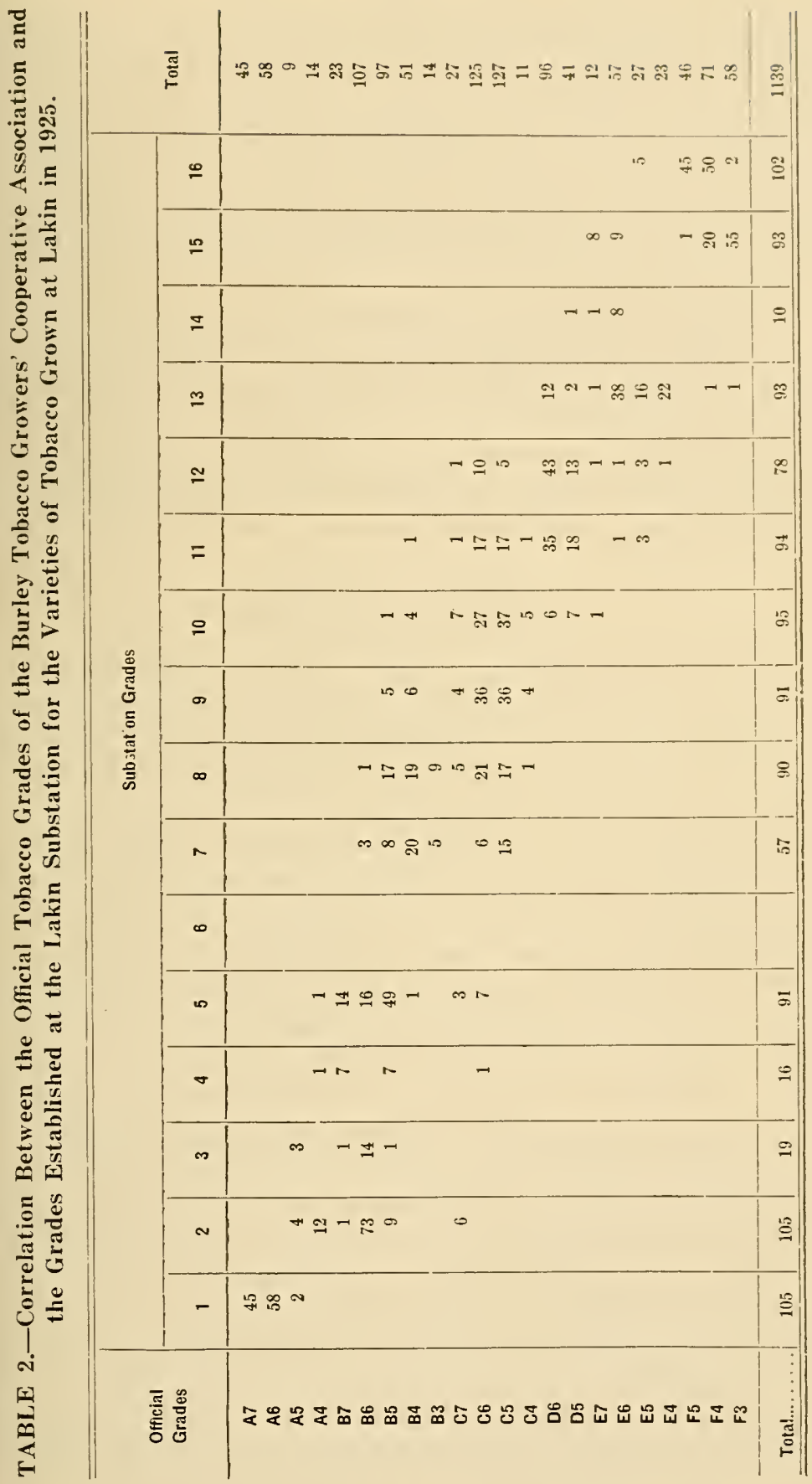


Under substation Grade 1, 105 samples were found which we placed in this grade. This same tobacco at Huntington was plac mainly in official grades A7 and A6. Similarly, there were 105 sa ples' which were placed in substation Grade 2, and this same tobac was placed chiefly in official grade B6. It is evident from Table 2 th in general there was a fairly close agreement between the substati grades and the official grades, although considerable variation occurr in certain instances.

In 1925 the difference between the average value of the variet per acre, based on the official grades, and that based on the substati grades, was $\$ 1.80$. Prior to 1925 , only the substation grades were ava able and it was upon the basis of these grades that yields and valu were determined. In view of the correlation of grades by the tr systems, the yields and values based on the substation grades may considered as a trustworthy index of the yields and values based the official grades.

\section{Data Collected in 1925}

As has been previously stated, the tobacco produced on each p. in 1925 was first graded and labeled, and then shipped to the Huntir ton Branch of the Burley Tobacco Growers' Cooperative Associati where it was regarded according to official standards and then sold the leaf tobaceo market. The average yield of tobacco in pounds $p$ acre and its value for each variety are shown by grades in Table 3.

In columns $2,4,6$, and 8 are given the yields per acre in poun for grades $\mathrm{A} 7$ and $\mathrm{A} 6, \mathrm{~A} 5$, and $\mathrm{A} 4$, respectively. (These yields a recorded in round numbers only. On the other hand the values 1 corded in the adjacent columns were computed by multiplying $t$ weight, carried to one decimal, by the auction price per hundr pounds, which may be found at the bottom of the table.) Of the fo classes of tobacco just mentioned, A4 on the average commands $t$ highest price on the market. Considering all the classes of the grade (flyings) together, it is apparent that Lockwood (U. S. D. A and White Twist Bud each produced considerable more tobacco of th grade than did any other variety in the test. Beinhart, Judy's Pric No. $10 \mathrm{Ba}$, No. 9a, and S. B. No. 1 each produced somewhat more th 250 pounds of $\mathrm{A}$ grade tobacco. The least amount of this grade tobacco was produced by Pepper which was closely followed by A. 7 and No. $10 \mathrm{Fa}$.

In a similar manner, the yields of the several varieties and strai of tobacco, with respect to grades B, C, D, E, and F, might be d cussed. This does not seem worth while, however, in view of the fa 
it the rata in 'Table 3 are from only one year's work. 'The table is blished in extended form, primarily to show the different grades of aceo produced hy the several varieties in the test.

l'he values of the various grades at the time the 1925 erop was rketerl are also shown. In general, grades $44, \mathrm{~B} 7, \mathrm{~B} 6, \mathrm{~B} 5, \mathrm{~B} 4, \mathrm{~B} 3$, , and ('j) brought the lighlest priees per pound, whereas grades E7, . Ft, and Fo brought the lowest. Considering the last four grades cether, it may be of some interest to point out which varieties procerl relatively high and which relatively low yields. Lockwood (U. D. A.) Was the highest producer of the low grades with a total of t pounds, and the Inuntington strain of Loekwood came second with otal of 37.9 pounds. The rarieties No. 9, No. 10 Ba, Kentucky Selecn. A. S. T. Beinhart, and Halley ranged in production of these inior grades from 306 to 337 pounds. Two varieties gave low yields, mely. Pepper with a total of 163 pounds and Red with a total of 167 linds.

The ratios (expressed in percentages) of the total average yield lumns $8,10,12,14,16,18,20$, and 22 , Table 3 ) of the aforemenned more valuable grades, to the total average yield (column 46) the crop for each variety in 1925, have been calculated and are given the following list, in which the varieties are arranged in a descend: order with regard to their ratios. In other words, the varieties ich are named first produced the greatest relative amount of high de tobacco. The varieties together with their pereentages of good Ide tobacco are as follows: Kelley, 58; Pepper, 55; No. 10 Ba, 51 ; ly's Pricle, 41 ; No. 10 Fa, 40; No. 9, 37 ; A. S. 7, 33 ; Lockwood (U. D. A.). 31 ; W. B. U. T., 30 ; Loekwood (Huntington), 30 ; Beinhart, Kentucky Selection, 28 ; No. 9a, 26 ; Red, 22 ; S. B. No. 1, 21 ; Hal18; and White Twist Bud, 13. It is apparent that in 1925 Kelley, sper, and No. 10 Ba produced the highest percentages, by weight, the better grades of tobacco.

\section{DATA COLLECTED DURING FOUR YEARS}

It has already been stated that in 1922,1923 , and 1924 the several ieties and strains of tobacco in the experiments herein reported 'e graded only at the Lakin substation. The tobaceo on each plot ; graded and the weight of each grade determined in a manner ilar to that followed in 1925. Each grade was given a ralue based current market prices for that particular year. In this way the a were recorded and collected in a table each year somewhat like ()le 3 except that the yields and values were based on the tobacco des made up at the substation. 


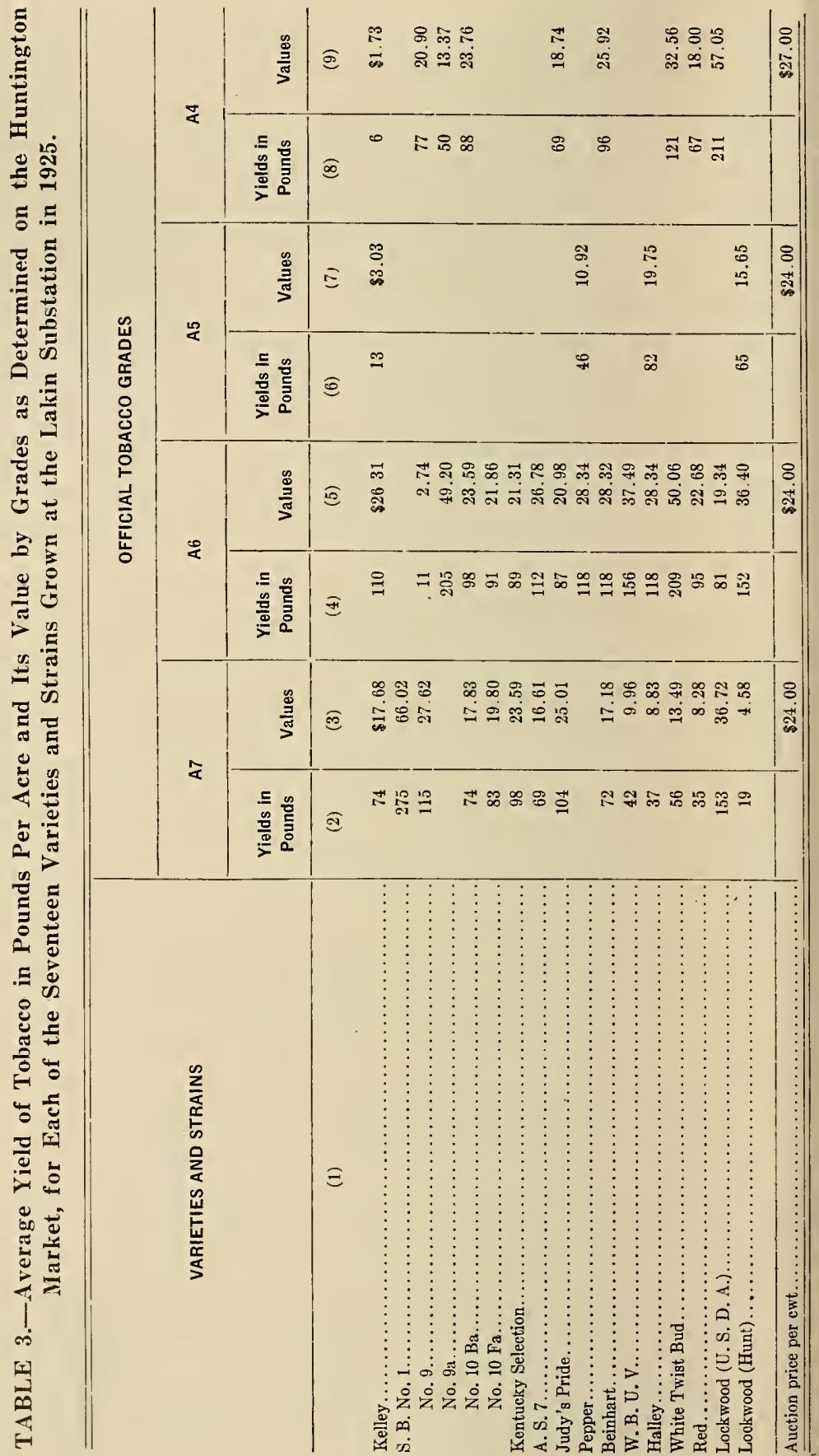




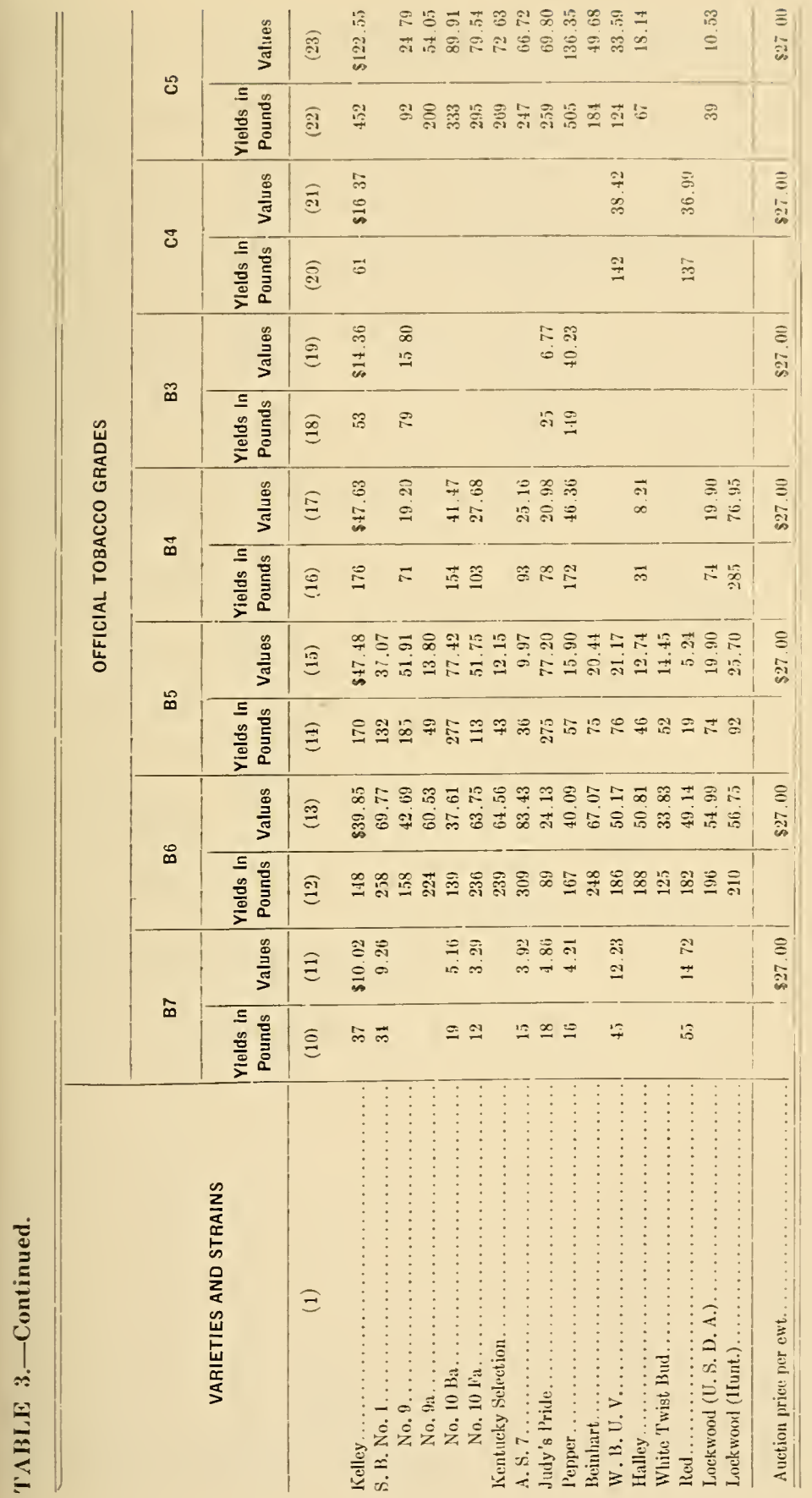




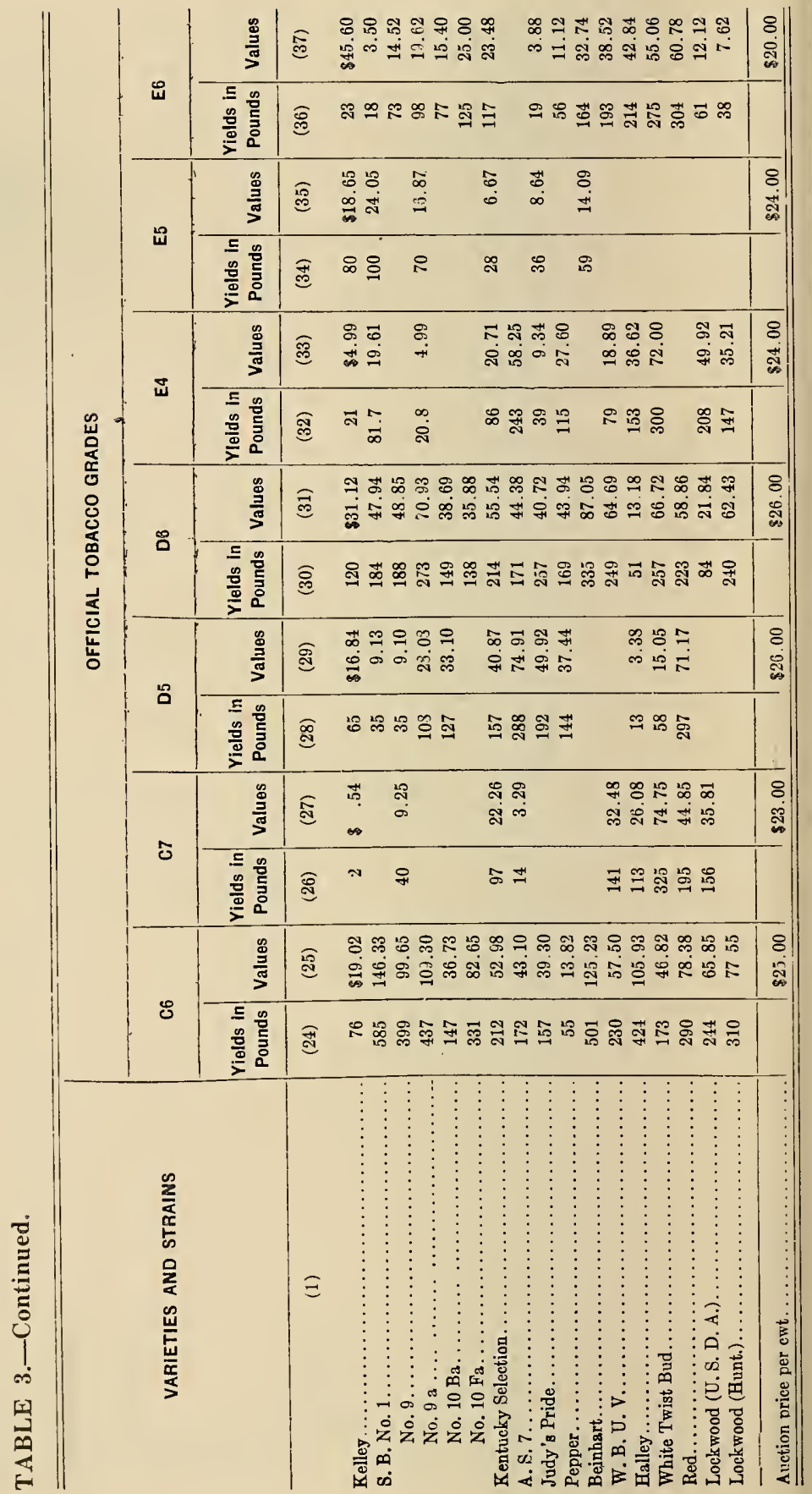




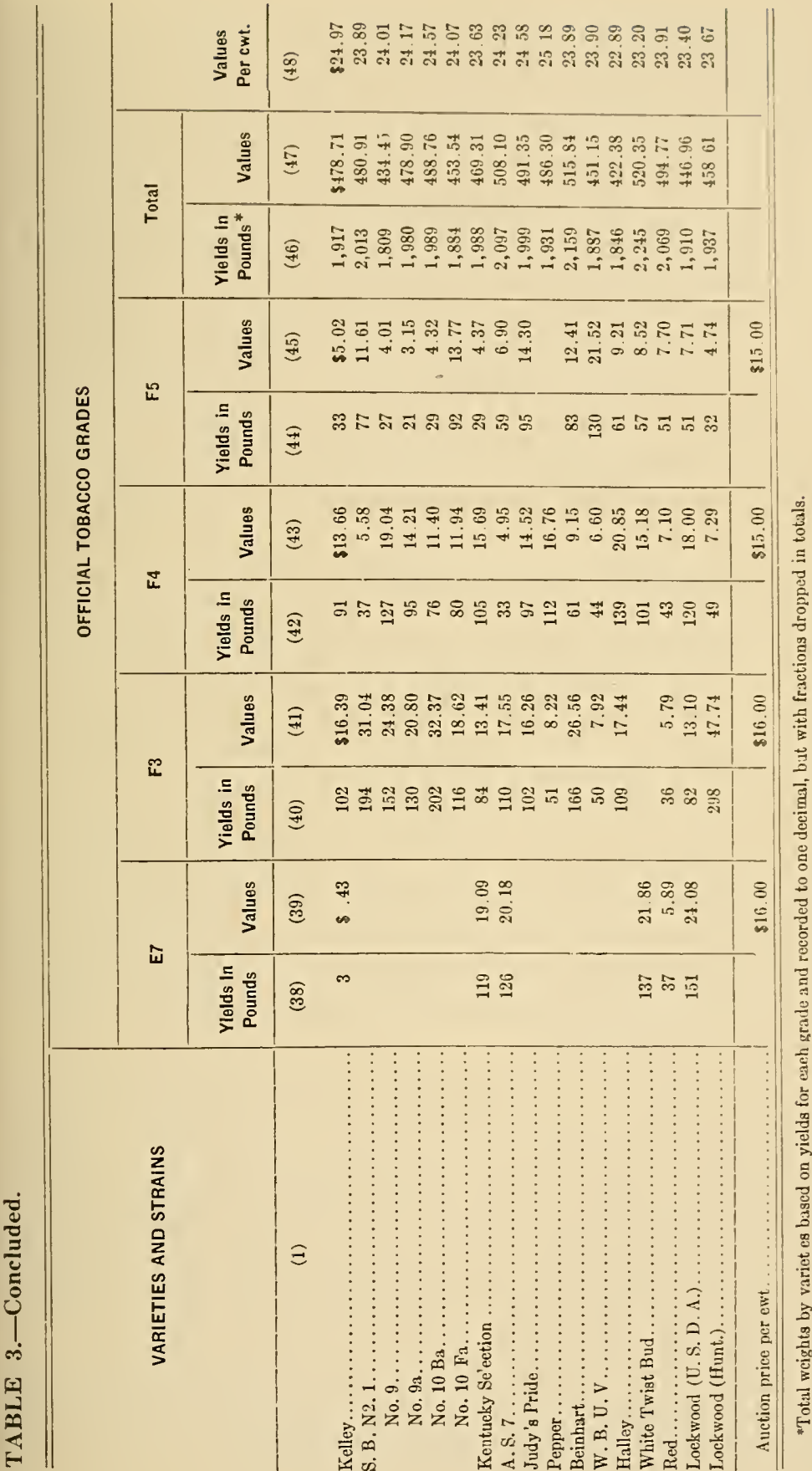


The total average yield of tobacco in pounds per acre and estimated total value for each variety, for each of the three ye 1922, 1923, and 1924, are brought together in Table 4 . In the sa table are shown the total average yields and the actual values of 1925 crop, based on the official grades, on the Huntington market.

In column 1 of Table 4 the varieties and strains of tobacco arranged according to the values of their average annual yields, wh are recorded in column 11 . The average annual value for any $p$ ticular variety was obtained by adding together the yearly values that variety recorded in columns $3,5,7$, and 9 and dividing the s? by four. The average yiclds in column 10 are obtained in a simi. manner. The value per hundred pounds of tobacco (column 12) any variety was computed by dividing the average value of tl variety by its average yield in pounds and multiplying the quotid by 100 .

Considering the varieties which were grown for four years, it apparent from column 11 that there were four of them whose yie had an average annual value somewhat greater than $\$ 500$ per ac These rarieties were White Twist Bud, Red, Pepper, and Kelley, which, the first named variety had considerably the highest val The three varieties with the lowest average annual value were I $10 \mathrm{Fa}$, W. B. U. V., and No. 9.

The rank of the four varieties which gave the highest avera yields (column 10) is the same as their rank with respect to avera annual values. The average yield per acre of White Twist Bud heavy dark tobaceo) was 2,264 pounds; of Red, 2,144 pounds; Pepper, 2,043 pounds; and of Kelley, 2,016 pounds. The first t varieties gave average annual yields of more than 100 pounds in exce of the last two varieties.

With respect to average values per hundred pounds' of tobac (column 12), Kelley (\$25.00) ranked first, Pepper (\$24.73) second, R. (\$23.66) third, and White Twist Bud (\$23.55) fourth. It should noted that the rank of these four varieties with respect to avera values per hundred pounds is just the reverse of what it was wi respect to average yields' (column 10) and average values (colur 11). The extreme difference in the average values per hundred poun of the four varieties is $\$ 1.41$.

Beinhart was grown in only three of the four years in which $t$ experiment was under way, but in each of those three years it rank near the top with respect to yield and value. 
促

\begin{tabular}{|c|c|c|c|}
\hline \multicolumn{2}{|c|}{ 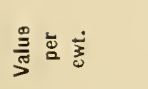 } & 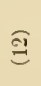 & 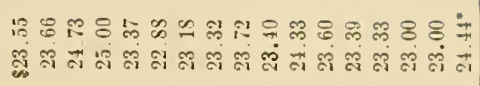 \\
\hline \multirow{2}{*}{ 总 } & $\frac{\stackrel{d}{3}}{5}$ & $\Xi$ & 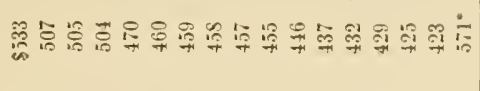 \\
\hline & 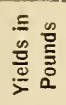 & $\stackrel{\ominus}{\ominus}$ & 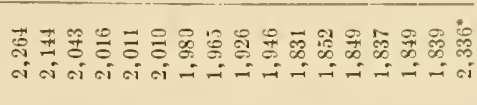 \\
\hline \multirow{2}{*}{ 芯 } & 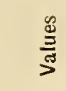 & क्र & 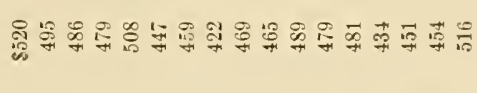 \\
\hline & 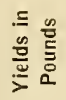 & $\widehat{\infty}$ & 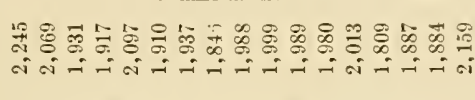 \\
\hline
\end{tabular}

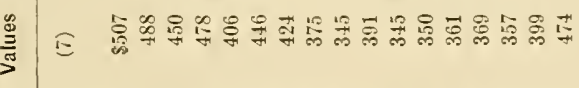
离

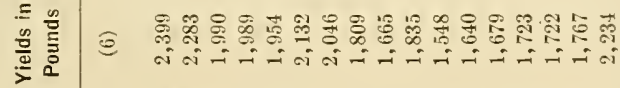

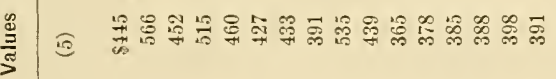

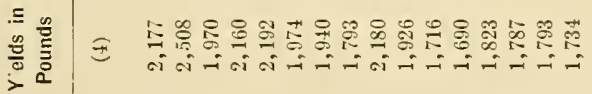

ป
os 0 ญี

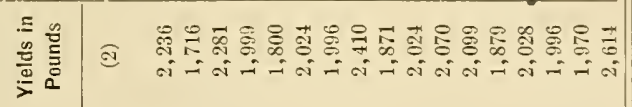




\section{CONCLUSION}

Under the conditions of the tobacco varietal experiments descri in this bulletin, the varieties White Twist Bud, Red, Pepper, and Ke] had the greatest average values per acre for the four years the exp ment was under way. Kelley and Pepper were somewhat superior quality to White Twist Bud and Red.

On the basis of only three years' work, Beinhart gives promise being a high yielder for the locality in which it was tested. 



\section{HECKMAN \\ BINDERY INC.}

\section{JUNE 99}

N. MANCHESTER INDIANA 46962 
